\title{
A Independência Real das Agências Reguladoras no Brasil
}

The Actual Independence of Regulatory Agencies in Brazil

\section{RESUMO}

Propósito - $\mathrm{O}$ artigo busca analisar a independência formal e a independência real das agências reguladoras no Brasil, nos diversos aspectos que a estruturam.

Metodologia/abordagem/design - A análise apoia-se nas perspectivas histórica, doutrinária e institucional de direito comparado para a construção dos conceitos de regulação e agências reguladoras, abordando as questões da legitimidade e controle desses entes em um Estado Democrático de Direito.

Resultados - O estudo conclui que o transplante das estruturas legais que dão suporte à independência das agências reguladoras tem baixa eficácia frente às culturas normativa e política pré-existentes, o que poderá levar à redução de sua independência real.

Implicações Práticas - Espera-se que este artigo possa apoiar o trabalho de pesquisadores interessados nas relações das teorias da regulação com o histórico das agências reguladoras no Brasil.

Originalidade/relevância do texto - $\mathrm{O}$ artigo sintetiza conceitos relativos à regulação e às agências reguladoras, e sua evolução nos Estados Unidos e no Brasil, com foco nas questões de sua independência formal e real. As recentes propostas de modificações normativas e o dilema que se estabelece entre a independência das agências reguladoras e a agenda do Governo Federal são também apresentados.

Palavras-chave: regulação; agências reguladoras; independência formal; independência real; Brasil.

*Bacharel em Direito pela Universidade Federal de Juiz de Fora. Especialista em Ciências Criminais pela Universidade Cândido Mendes. Graduado em Engenharia Mecânica pela Universidade Federal de Santa Catarina, com MBA pela COPPEAD/UFRJ. Especialista em Engenharia de Produção pela COPPE/UFRJ e Mestre em Sistemas de Gestão pela Universidade Federal Fluminense. Contato: paulossampaio@gmail.com. Endereço: SQS 305, Bloco H, ap. 302, Brasília/DF, CEP 70352-080. 


\begin{abstract}
Purpose - This article analyses the "formal" and the "actual" independence of regulatory agencies in Brazil, considering the several aspects of their structure.

Methodology/approach/design - This study is based on historical, doctrinal and institutional perspectives in comparative law designed to frame the concepts of regulation and regulatory agencies, by analyzing features of legitimation and control in a country characterized by the existence of the rule of law. The article adopts the format of review of the literature.

Findings - This study concludes that the transplant of legal structures that support the independence of regulatory agencies from abroad has low efficiency in the preexisting normative and political cultures, what may lead to a reduction of their actual independence.

Practical Implications - It serves as groundwork for researchers interested in the relationships between regulation theories and the history of regulatory agencies in Brazil.

Originality/value - This article presents a synthesis of the concepts related to regulation and regulatory agencies, and their evolution in the United States and Brazil, focusing on formal and actual independence issues. The recent bill regarding regulatory agencies under scrutiny in the Brazilian Congress and the dilemma between the independence of regulatory agencies and the federal government agenda are also presented in this article.
\end{abstract}

Keywords: regulation; regulatory agencies; formal independence; actual independence.

\title{
1. Introdução
}

A independência das agências reguladoras tem sido objeto de intenso debate na doutrina do direito regulatório e na política brasileira. Consolidada no direito estadunidense, a independência das agências, seu conteúdo e extensão são objeto de dissídio na doutrina e na prática de sua atividade.

Este artigo tem por objetivo analisar a independência formal e a independência real das agências reguladoras no Brasil, identificando as atuais tendências para a independência real no ambiente brasileiro.

Para tanto, a primeira e a segunda seção apresentam os conceitos de regulação e agências reguladoras, sob a óptica de doutrinadores brasileiros e 
internacionais. As duas seções seguintes apresentam uma breve síntese da evolução das agências reguladoras nos Estados Unidos e de seu histórico no Brasil, permitindo a compreensão de sua identidade nos contextos históricos que as originaram. A questão da independência formal é tratada no tópico seguinte, com o apoio da doutrina nacional e internacional, com destaque para a estabilidade dos dirigentes como núcleo central da independência dos entes reguladores. A legitimidade das agências, igualmente objeto de divergência na doutrina, é analisada mais adiante.

Após a construção conceitual, analisa-se a independência real das agências no Brasil, e dos mecanismos utilizados para limitá-la na prática. A questão do controle das agências - externo e social - é apresentada de forma breve no tópico seguinte, seguida de uma apresentação das recentes tendências relativas à independência real das agências no país, com destaque para o Projeto de Lei no 3.337/2004.

Em sua seção final, é apresentada conclusão da reduzida eficácia do transplante legal que assegurou independência às agências reguladoras e a importância do estabelecimento de garantias à independência dos entes reguladores como solução de compromisso que assegurem a implementação da agenda do governo e a eficácia de funcionamento dos setores regulados.

\section{Regulação: conceitos preliminares}

Não há um consenso doutrinário para o significado de regulação, pois o conceito atribuído à regulação varia de acordo com a teoria da regulação adotada. ${ }^{1}$ Morgan e Yeung (2007) apresentam uma tipologia das teorias de

${ }^{1}$ Há diversas tipologias das teorias de regulação. As teorias do interesse público atribuem ao legislador e outros responsáveis pela arquitetura e execução da regulação o desejo de buscar objetivos coletivos para a promoção do bem-estar da comunidade. As teorias do interesse privado, por outro lado, são céticas quanto ao interesse público por parte de legisladores e formuladores de políticas públicas, reconhecendo que a regulação com frequência beneficia grupos particulares da sociedade diversos daqueles que ostentava buscar beneficiar. Assim, as teorias do interesse privado concebem a regulação como o concurso entre participantes que buscam a apropriação de rendas (rent-seeking) no jogo regulatório, analisando a maneira pela qual os processos políticos e de formulação das leis e normas podem ser utilizadas por estes participantes para assegurar benefícios regulatórios para si 
regulação que as divide nas Teorias do Interesse Público - nas quais se incluem as definições de Selznick (1985), Ogus (2004), Aranha et al. (2009) e Salomão Filho (2008), entre outras, nas Teorias do Interesse Privado e nas Teorias Institucionalistas - que incluem as Teorias dos Sistemas de Luhmann $^{2}$ e Teubner ${ }^{3}$, a Teoria das Redes e a Teoria do Espaço Regulatório, esta exemplificada pela definição de Aranha (2012).

Selznick (1985) define a regulação como o "controle, exercido de forma sustentada e focada, por uma agência pública sobre atividades valorizadas por uma comunidade". ${ }^{4}$

Ogus (2004) enxerga a regulação como o:

"exercício necessário de um poder coletivo através do Governo de forma a sanar 'falhas de mercado' para proteger o público de males como o comportamento monopolista, a competição destrutiva, o abuso do poder econômico privado ou 0 efeito de externalidades". ${ }^{5}$

Para Aragão (2004) a regulação é:

"0 conjunto de medidas legislativas, administrativas e convencionais, abstratas ou concretas, pelas quais o Estado, de maneira restritiva da liberdade privada ou meramente indutiva, determina,

mesmos. As teorias institucionalistas analisam as interações regulatórias de forma mais abstrata. Por exemplo, o foco da teoria dos sistemas está na dinâmica dos sistemas legal, econômico e político, e nas interações entre esses sistemas. As abordagens em rede e do espaço regulatório se incluem entre as teorias institucionalistas. Estas teorias observam detalhadamente a dinâmica de um sistema regulatório a partir de um contexto regulatório específico, e.g. saúde, educação, telecomunicações etc. (MORGAN, Bronwen e YEUNG, Karen. An Introduction to Law and Regulation. Cambridge: Cambridge University Press, 2007, p. 8-9).

${ }^{2} \mathrm{~A}$ Teoria dos Sistemas de Niklas Luhmann é apresentada na obra "Introdução à Teoria dos Sistemas". Petrópolis: Vozes, 2009.

${ }^{3}$ A Teoria dos Sistemas de Günther Teubner é apresentada na obra "O Direito como Sistema Autopoíético". Lisboa: Fundação Calouste Gulbekian, 1993.

${ }^{4}$ Cf.SELZNICK, P. Focusing Organizational Research on Regulation. In: R. Noll (org.). Regulatory Policy and the Social Sciences. Berkeley: University of California Press, 1985, p. 363-367.

${ }^{5}$ Cf.OGUS, Anthony. Regulation: Legal Form and Economic Theory. Portland: Hart, 2004. 
controla ou influencia o comportamento dos agentes econômicos, evitando que lesem os interesses sociais definidos no marco da Constituição e orientando-os em direções socialmente desejáveis". ${ }^{6}$

Aranha et al. (2009) defendem que a regulação é o regime jurídico regulatório que corresponde a:

"um conjunto de disposições normativas e administrativas caracterizadas pelo seu caráter conjuntural de influência ou controle sobre 0 ambiente regulado mediante batimento entre resultados esperados e resultados efetivamente alcançados". ${ }^{7}$

Salomão Filho (2008) define regulação como:

"toda forma de organização da atividade econômica através do Estado, seja a intervenção através da concessão de serviço público ou o exercício de poder de polícia".

Aranha (2012), no âmbito da teoria institucionalista do espaço regulatório, propõe a seguinte definição:

"Regulação é um espaço regrado de manifestação política e não uma forma de relação entre atores predeterminados. A projeção política dos atores setoriais permite este novo enfoque da questão regulatória como a presença de diversos atores setoriais - governo, parlamento, órgãos de controle hierárquico, interorgânico e social, grupos de pressão, mercado, interessados, usuários efetivos, usuários potenciais - em torno a um regime jurídico regulatório não mais visto como uma pauta de relação

${ }^{6} \mathrm{Cf} . \mathrm{ARAGÃO}$, Alexandre Santos de. Agências reguladoras e a evolução do direito administrativo econômico. Rio de Janeiro: Forense, 2004. p. 37.

${ }^{7}$ Cf.ARANHA et al. Direito, Estado e Telecomunicações: dos primórdios ao novo modelo regulatório. In: Revista de Direito, Estado e Telecomunicações, v.1, n.1, Brasília: Universidade de Brasília, 2009, p. 19.

${ }^{8}$ Cf.SALOMÃO FILHO, Calixto. Regulação da atividade econômica: princípios e fundamentos jurídicos. São Paulo: Malheiros, 2008, p. 21. 
entre dois pólos bem definidos, mas como espaço de postulação de interesses legítimos." 9

Moreira (1997), analisando a doutrina internacional, destaca que há três conceitos jurídicos possíveis para a regulação: ${ }^{10}$

a) Em um sentido amplo, toda a forma de intervenção do Estado na economia, independentemente dos seus instrumentos e seus fins.

b) Em sentido menos abrangente, a intervenção estatal na economia por outras formas que não a participação direta na atividade econômica.

c) No sentido estrito, somente o condicionamento normativo da atividade privada, seja por lei ou qualquer instrumento normativo.

Para o autor,

"0 conceito de regulação deve abranger todas as medidas de condicionamento da atividade econômica, revistam ou não forma normativa. Na regulação haverá assim que distinguir os instrumentos de regulamentação normativa (lei ou outro instrumento) e as medidas administrativas ou outras de intervenção (concertação convencional, polícia administrativa, subsídios e outros incentivos, medidas de política financeira e monetária etc.) 0 essencial do conceito de regulação é alterar 0 comportamento dos agentes econômicos (produtores, distribuidores, consumidores) em relação ao que eles teriam se não houvesse regulação, isto é, se houvesse apenas as regras do mercado."11

\section{Algumas tipologias da regulação}

Embora haja numerosas tipologias formuladas pela doutrina, mostra-se oportuno apresentar algumas classificações apontadas na doutrina.

${ }^{9}$ ARANHA, M. (2012). Mimeo. Mestrado e Doutorado em Direito. Disponível em: http://www.marcioaranha.com/docProgramaEstadoeRegulacao2012.pdf. Acesso em: $13 / 03 / 2013$.

${ }^{10}$ MOREIRA, Vital. Autorregulamentação profissional e administração pública. Coimbra: Almedina, 1997, p. 34.

${ }^{11}$ Op. cit., p. 36.

Revista de Direito, Estado e Telecomunicações, v. 5, n. 1, p. 135-174 (2013)

DOI: https://doi.org/10.26512/lstr.v5i1.21565 
Prosser (1997) adota a seguinte tipologia da regulação, de natureza teleológica: ${ }^{12}$

a) Regulação dos monopólios, mimetizando o efeito das forças de mercado por meio de controles de preços e da qualidade de serviços.

b) Regulação da competição, criando as condições para sua existência e assegurando a continuidade de sua existência, através de fiscalização.

c) Regulação social, ligada à prestação de serviços públicos, onde a fundamentação não é primordialmente econômica ${ }^{13}$.

Majone (1996) apresenta as seguintes formas possíveis de regulação: ${ }^{14}$

a) Regulação pelo mercado, que se baseia na habilidade do mercado em corrigir distorções, através da alocação eficiente de recursos.

b) Regulação por órgãos reguladores, em que 0 mercado é acompanhado setorialmente por estruturas estatais técnicas.

c) Regulação endógena, onde a regulação se dá através da estatização dos prestadores dos serviços regulados.

d) Regulação por contrato, onde as regras contratuais são acordadas caso a caso, resumindo-se às formas firmadas nos contratos administrativos de concessão e permissão.

É oportuno destacar que teoricamente cada forma de organização do Estado pode levar à prevalência de determinados tipos de regulação. Em um Estado Liberal mínimo, cabe ao Estado assegurar a propriedade e os contratos essenciais ao bom funcionamento do mercado; a este cabe a regulação e coordenação das atividades econômicas. ${ }^{15}$

${ }^{12}$ Cf.PROSSER, Tony. Law and the Regulators. Oxford: Claredon Press, 1997, p. 56.

${ }^{13}$ Cf.MOREIRA, Vital. Autorregulamentação profissional e administração pública. Coimbra: Almedina, 1997, p. 34.

${ }^{14}$ Cf.MAJONE, Giandomenico. Regulating Europe. Londres: Routledge, 1996, p. 927.

${ }^{15}$ Cf.ARANHA et al. Direito, Estado e Telecomunicações: dos Primórdios ao Novo Modelo Regulatório. In: Revista de Direito, Estado e Telecomunicações, v.1, n.1, Brasília: Universidade de Brasília, 2009, p. 19. 
Em um Estado de Bem-Estar Social, cabe a este prover os serviços de forma direta, atuando como executor dos serviços públicos e agente promotor do desenvolvimento econômico social, depreendendo-se a prevalência da regulação endógena. ${ }^{16}$

No Estado Regulador, a Administração Pública assume os papéis de gerenciamento e coordenação através de controle e intervenção indireta nos mercados. O mercado é tomado como instrumento para a concretização de direitos fundamentais, por meio do acompanhamento da conjuntura, custos, infraestrutura, serviços, tarifas e cobertura, entre outros. A forma de regulação por órgãos reguladores pode ser adotada quando há a possibilidade de concorrência. Nos denominados monopólios naturais ${ }^{17}$, os contratos administrativos são o instrumento jurídico do Estado para alcançar seus objetivos na prestação de serviços públicos. ${ }^{18}$

Será adotada neste artigo a definição de Moreira (1997), considerando todas as atividades das agências reguladoras, que correspondem ao conjunto básico de instituições regulatórias. ${ }^{19}$

\section{As agências reguladoras: natureza e características}

As agências reguladoras independentes tiveram sua gênese nos Estados Unidos. A partir da década de 80, diversos ordenamentos jurídicos adotaram as agências reguladoras, buscando uma maior eficiência na implementação de políticas públicas e uma melhor prestação de serviços públicos. Todavia, houve por parte de diversos doutrinadores uma reação crítica àquelas instituições originadas no direito estadunidense.

${ }^{16}$ Op. cit., p. 13-14.

${ }^{17}$ Os monopólios naturais ocorrem quando há menores custos para a sociedade se a produção ou prestação de serviço é realizada por uma empresa apenas, ao invés de diversas ou muitas. (MORGAN, Bronwen e YEUNG, Karen. An Introduction to Law and Regulation. Cambridge: Cambridge University Press, 2007, p. 19).

${ }^{18} \mathrm{Cf}$. ARANHA et al. Direito, Estado e Telecomunicações: dos Primórdios ao Novo Modelo Regulatório. In: Revista de Direito, Estado e Telecomunicações, v.1, n.1, Brasília: Universidade de Brasília, 2009, p. 13-14.

${ }^{19} \mathrm{Na}$ lição de ARANHA (2009), são instituições básicas regulatórias a regulamentação, o monitoramento, a fiscalização, o planejamento, a ordenação, o fomento, as outorgas de serviços e a alocação de meios.

Revista de Direito, Estado e Telecomunicações, v. 5, n. 1, p. 135-174 (2013)

DOI: https://doi.org/10.26512/1str.v5i1.21565 
Na doutrina italiana, Amato (1997) questiona a natureza das autoridades semi-independentes, equivalentes às agências reguladoras naquele país. ${ }^{20}$

$\mathrm{Na}$ doutrina francesa, D'Arcy e Dreyfus (1997) entendem que uma autoridade administrativa independente é caracterizada pela natureza da função delegada, pela forma de nomeação de seus dirigentes para um mandato e em especial pela impossibilidade de sua exoneração de ofício, salvo na hipótese de falta grave ou de incapacidade para o exercício das funções. ${ }^{21}$ Os autores entendem que há dificuldades de integração do conceito de agências reguladoras no direito administrativo francês. ${ }^{22}$

Moreira (1997) defende que os entes reguladores independentes constituem uma forma distinta das autarquias, a administração independente. Para o autor,

"É evidente que a administração independente não se pode integrar no conceito de administração indireta, dada sua independência

${ }^{20}$ Nas palavras do autor, "É nell'ambito di questo complessivo cambiamento che noi (noi europei e noi italiani) abbiamo il nostro ventaglio di nuove autorità: ora per sovrintedere e arbitrare il gioco della concorrenza, ora por imporgli moduli e garanzie di trasparenza...si ritiene più corretto affidare a organi più tecnici e più isolati dagli indirizzi politico-amministrativi. Si tratta in tutti i casi di organi no amministrativi? Le loro funzioni sono in tutti $i$ casi non amministrative? Sta morendo, con loro, il diritto amministrativo?" (AMATO, Giuliano. Autorità SemiIndipendenti ed Autorità de Garanzia. In: Rivista Trimestrale di Diritto Publico, ano XLVII, p. 658.).

${ }^{21}$ Nas palavras de D'Arcy e Dreyfus: "Pour son mode de nomination et les fonctions qu'il remplit, Le Conseil de la Politique Monétaire est donc comparable à une autorité administrative indépendant, Le Conseil comprend, autre cas trois personnes, six autres nomes par décret pour neuf ans. Les uns et les autres ne peuvent être révoques, sauf à la demande du Conseil en cas de faute grave ou s'ils sont devenues incapables d'exercer". (D'ARCY, François e DREYFUS, Françoise. Les Institutions Politiques et Administratives de la France. Paris: Economia, 1997, p. 363).

${ }^{22}$ Para François D'Arcy e Françoise Dreyfus é difícil conciliar o conceito das agências reguladoras às instituições do direito administrativo na França: “Alors, q'il s'agit d'une pratique courante et reconnue dans certains pays tels les Etats Unis, ele reste em France, difficile à concilier avec les príncipes sur les quels reposent tradionnellement nos institutions politiques et administratives". (D'ARCY, François e DREYFUS, Françoise. Les Institutions Politiques et Administratives de la France. Paris: Economia, 1997, p.363). 
organizacional e funcional, em contradição com a natureza em geral instrumental daquela". ${ }^{23}$

As agências reguladoras foram introduzidas no Brasil na segunda metade da década de 90. Nas diversas leis de criação das agências reguladoras, estas foram definidas como autarquias submetidas a regime especial. Todavia, as leis de criação não definem de forma clara o conceito de regime especial adotado nos diplomas legislativos.

A introdução desta figura jurídica no direito administrativo brasileiro foi - e ainda é - objeto de grande divergência entre os doutrinadores pátrios, e até de rejeição do modelo proposto por doutrinadores mais tradicionais. As dificuldades de adaptação do instituto foram destacadas por Justen Filho (2002), que, no estudo das agências reguladoras no direito brasileiro, alerta para as dificuldades na introdução de institutos de direito estrangeiro no direito nacional:

“(...) a compatibilização de um instituto estrangeiro com o Direito nacional é tanto mais difícil quanto maior a diversidade do sistema jurídico (mas também social) de sua origem. É que um instituto usualmente é gerado, ao longo do tempo, como um processo históricocultural no âmbito de determinada sociedade. A modelação do sistema e dos diversos institutos jurídicos é resultado da inter-relação entre as diversas instituições sociais. Portanto, cada instituto reflete as características e peculiaridades de certa sociedade e da circunstância histórica correspondente." 24

Di Pietro (1999) defende que a "agência é apenas mais um modismo introduzido no direito brasileiro por conta da globalização"25. A autora endente que as agências reguladoras, por sua natureza de autarquias, estão sujeitas ao controle administrativo ministerial. ${ }^{26}$

${ }^{23}$ Cf.MOREIRA, Vital. Administração autônoma e associações públicas. Coimbra: Coimbra Editora, 1997, p. 130.

${ }^{24}$ Cf.JUSTEN FILHO, Marçal. O Direito nas agências reguladoras independentes. São Paulo: Dialética, 2002, p. 286.

${ }^{25}$ Cf.DI PIETRO, Maria Sylvia Zanella. Direito administrativo. São Paulo: Atlas, 1999 , p. 385.

${ }^{26}$ Nas palavras de Di Pietro: "Como autarquias que são, estão sujeitas à tutela ou controle administrativo exercido pelo Ministério a que se acham vinculadas. 
Mello (2002) entende que não há peculiaridade nas agências reguladoras, nem no regime autárquico especial ao qual estão submetidas. No seu entendimento:
"Ora, "independência administrativa" ou "autonomia administrativa", "autonomia financeira", "autonomia funcional", e "patrimonial e da gestão de recursos humanos" ou de quaisquer outros que lhe pertençam, "autonomia nas decisões técnicas", "ausência de subordinação hierárquica", são elementos intrínsecos à natureza de toda e qualquer autarquia, nada acrescentando ao que lhes é inerente. Nisto, pois, não há peculiaridade alguma; o que pode ocorrer é um grau mais ou menos intenso destes caracteres." 27

Silva (2002) entende que a ideia de uma administração independente, não inserida no Poder Executivo e criada pelo Legislativo sem previsão constitucional não é compatível com o princípio de separação de poderes. ${ }^{28}$ Para o autor, a regulação por agências tem por objetivo "despolitizar a atividade regulatória, atribuindo aos órgãos independentes a decisão final sobre temas específicos, sem possibilidade de recurso à Chefia da Administração ou aos Ministérios supervisores, ressalvado o controle pelo Judiciário." 29

Moreira (1999) identifica nas agências reguladoras as seguintes características $^{30}$ :
a) ausência de vínculo hierárquico formal com a Administração central, com previsão de mandato fixo dos dirigentes e estabilidade;
b) independência de atuação, com exclusão do controle tutelar;

Todavia, como autarquias de regime especial, seus atos não podem ser revistos ou alterados pelo Poder Executivo." (DI PIETRO, Maria Sylvia. Parcerias na Administração Pública. São Paulo: Atlas, 1999, p. 132).

${ }^{27}$ MELLO, Celso Antônio Bandeira de. Curso de direito administrativo. São Paulo: Malheiros, 2002, p. 160.

${ }^{28}$ Cf.SILVA, Francisco Quadros. Agências reguladoras: a sua independência e o Princípio do Estado Democrático. Curitiba: Juruá, 2002, p. 149.

${ }^{29}$ Idem, Ibidem.

${ }^{30}$ Cf.MOREIRA, Egon Bockman. Agências Administrativas, Poder Regulamentar e o Sistema Financeiro Nacional. In: Revista de Direito Administrativo, n.218, p.93, out/dez 99. 

c) poder de editar normas regulamentares; e,
d) poder de decidir controvérsias definitivamente, ressalvado o controle judicial.

Para Aranha (2009), as entidades reguladoras são neutras, porém vinculadas à ideologia adotada pela Constituição. ${ }^{31}$ No mesmo sentido, Feintuck (2010) considera que as ações do ente regulador devem ir além da justificativa econômica: os valores políticos e sociais de natureza constitucional devem ser incorporados e priorizados na regulação. ${ }^{32}$

\section{Síntese da Evolução das Agências Reguladoras nos Estados Unidos}

Shapiro (2010) relata que a primeira agência reguladora americana - a Interstate Commerce Commission - já detinha entre suas características a independência dos Poderes Executivo e Legislativo, ligada à ideia dos progressistas da consolidação de uma burocracia especializada, cujo trabalho seria executado de forma independente dos ciclos eleitorais, e o Conselho de Diretores, de forma a reduzir os riscos de corrupção, pois cada diretor estaria observando os demais. ${ }^{33} \mathrm{~A}$ agência combinava poderes normativos, de execução e judiciais. ${ }^{34}$ Justen Filho (2002) relata que a independência da Interstate Commerce Commission teve origem em uma situação política específica ocorrida dois anos após sua criação. ${ }^{35}$

${ }^{31}$ Para Aranha (2009, p. 14), “[a]s entidades de regulação são neutras quanto à aplicação isenta das estações de humor político, embora conscientes de sua presença no jogo político e de seus reflexos no ordenamento jurídico, bem como da vinculação à ideologia constitucionalmente adotada."

${ }^{32}$ Cf.FEINTUCK, Mike. Regulatory Rationales Beyond the Economic: In Search of the Public Interest. In: BALDWIN, Robert; CAVE, Martin; LODGE, Martin (org.). The Oxford Handbook of Regulation. Oxford: Oxford University Press, 2010, p. 39-63.

${ }^{33}$ Cf.SHAPIRO, Martin. A Comparison of US and European Independent Agencies. In: ROSE-ACKERMAN, Susan e LINDSETH, Peter. Comparative Administrative Law. Cheltenham: Edward Elgar, 2010, p. 293-294.

${ }^{34}$ Op. cit., p. 294.

${ }^{35}$ Relata Justin Filho: "Quando criada em 1887, a ICC não apresentava a configuração que significou a introdução de um novo modelo. Tal derivou de uma circunstância que nunca foi explicada satisfatoriamente. Em 1889, o republicano 
Horwitz (1999) identifica as seguintes fases e finalidades na evolução das agências reguladoras americanas: ${ }^{36}$

a) Era Progressiva (1900 a 1916) - agências destinadas a amenizar a instabilidade econômica e social causadas pelo surgimento e impacto das grandes corporações. São exemplos a Interstate Commerce Commission, a Federal Trade Commission e o Federal Reserve System.

b) New Deal (1930-1938) - o papel das agências era criar fortes controles de preço e entrada em mercados específicos, a fim de estabelecer cartéis estáveis, em resposta a anarquia do mercado durante a Grande Depressão. Sua finalidade era a proteção da produção. São exemplos o Civil Aeronautics Board e a Federal Communications Commission.

c) Agências da Grande Sociedade (1965-1977) - agências reguladoras sociais, estabelecidas em resposta aos movimentos de reformas liberais, preocupadas com o impacto social dos negócios (sob a ótica dos consumidores) e não com os aspectos econômicos per se. São exemplos a Environmental Protection Agency e a Occupational Safety and Health Administration.

Sunstein (1990) entende que a criação das agências reguladoras durante o New Deal representou uma transferência do poder dos estados para o governo federal, com crescimento massivo da burocracia federal,

Benjamin Harrison assumiu a Presidência dos Estados Unidos. Anteriormente, Harrison se notabilizara como advogado das empresas de estradas de ferro, setor cujo controle era precisamente o objeto de atividade da ICC. A maioria democrata do Congresso, alguns dias antes da posse do novo Presidente, aprovou a Lei de dois de março de 1889, através da qual assegurou ampla autonomia à ICC, inclusive no tocante à orçamento, pessoal e administração, e retirou-a do âmbito de abrangência do departamento do interior. Uma alteração fundamental consistiu em eliminar a possibilidade de demissão ad nutum dos membros da comissão. Embora o Chefe do Executivo detivesse competência para nomear os conselheiros, a eles foi atribuída garantia do exercício da função até o término do mandato. Somente poderiam ser demitidos em caso de verificação de uma falta grave, explicitamente relacionada em elenco legislativo exaustivo." (JUSTEN FILHO, Marçal. O direito nas agências reguladoras independentes. São Paulo: Dialética, 2002, p. 76). ${ }^{36} \mathrm{Cf}$. HORWITZ, Robert Britt. The Irony of Regulatory Reform: the Deregulation of American Telecommunications. New York/Oxford: Oxford University Press, 1989. 
enfraquecimento do Poder Judiciário e dos controles legais sobre a política e a administração, concedendo ao Presidente poderes anteriormente exercidos pelo Congresso, pelos estados e pelos tribunais. ${ }^{37}$

Melo (2001) destaca que a fase relativa às agências reguladoras se estende até a década de 90, e que - com a exceção do Civil Aeronautics Board, as agências regulatórias passaram ao largo da onda desregulatória dos anos 80 , porém seu padrão de atuação alterou-se face às restrições dos recursos colocados à disposição das agências. ${ }^{38}$

É importante assinalar que, nos Estados Unidos, as agências regulatórias respondem ao Congresso e não ao Poder Executivo. A elaboração dos orçamentos é feito pelas próprias agências reguladoras e encaminhado diretamente ao Congresso. Apenas aspectos procedimentais do processo decisório são sujeitos à regulação congressual; o conteúdo substantivo da regulação é objeto de decisão interna autônoma, em função do poder normativo a elas concedido (rule making powers). ${ }^{39}$

\section{Síntese do histórico das agências reguladoras no Brasil}

Na década de 80, o governo conservador de Margaret Thatcher adotou uma série de políticas econômicas centradas na desregulamentação do setor financeiro, na desregulamentação do mercado de trabalho e na privatização das empresas estatais. $\mathrm{O}$ sucesso econômico do conjunto dessas medidas liberais influenciou o pensamento de economistas em todo o mundo, levando à prevalência de que a superação da crise econômica devia basearse na adoção de uma política econômica pautada na austeridade fiscal, no livre comércio e na privatização das empresas estatais.

O conjunto de políticas recomendadas pelo Banco Mundial ${ }^{40}$ e Fundo Monetário Internacional - organizações econômicas multilaterais sediadas

${ }^{37}$ Cf.SUNSTEIN, Cass. After the Rights Revolution: Reconceiving the Regulatory State. Cambridge: Harvard University Press, 1990, p. 23.

${ }^{38}$ Cf.MELO, Marcus André. A política da ação regulatória: responsabilização, credibilidade e delegação. Revista Brasileira de Ciências Sociais, v. 16, $\mathrm{n}^{\circ}$ 46, junho 2001, p. 58.

${ }^{39}$ Idem, Ibidem.

${ }^{40}$ Cabe destacar as recomendações do Relatório sobre o Setor Elétrico do Banco Mundial, de 1993: "Uma exigência para qualquer empréstimo no setor elétrico será Revista de Direito, Estado e Telecomunicações, v. 5, n. 1, p. 135-174 (2013)

DOI: https://doi.org/10.26512/lstr.v5i1.21565 
em Washington - para a superação da prolongada crise da dívida da América Latina foi denominado "Consenso de Washington"41 pela organização não governamental Instituto Petersen de Economia Internacional. Este conjunto de medidas foi adotado pelo Brasil e por outros países na década de 90 , com a privatização de diversas empresas estatais de serviços públicos no âmbito do Plano Diretor de Reforma do Estado, que tinha por objetivo redefinir o papel do Estado, que deixaria de ser o responsável direto pelo desenvolvimento econômico e social para se tornar indutor e promotor do processo. ${ }^{42}$

Para reduzir o temor dos investidores estrangeiros dos riscos da desapropriação, da manipulação política e das políticas de curto prazo relativa aos ciclos eleitorais, o governo brasileiro criou agências reguladoras, com relativa autonomia em relação ao Poder Executivo e ao processo político, baseadas no modelo adotado nos Estados Unidos. ${ }^{43}$

A independência das agências reguladoras, evitando comportamentos oportunistas pelo governo e pelas empresas, é considerada indispensável

um movimento explícito do país rumo ao estabelecimento de um quadro jurídico e processos regulatórios satisfatórios para o Banco. Para esse fim, em conjunção com outras iniciativas de âmbito econômico, o Banco exigirá dos países que estabeleçam processos regulatórios transparentes que sejam claramente independentes dos fornecedores de energia e que evitem interferência governamental nas operações cotidianas da companhia (pouco importando se a empresa é privada ou pública). (...) O papel dual do governo como operador e titular de serviços públicos conduziu o governo a intervenções frequentes nas operações do setor elétrico. Há, portanto, necessidade de se definir alguma forma de corpo regulatório como parte de um esforço governamental para redefinir os papéis respectivos do governo, concessionário e consumidores. Isso implica em uma mudança do tipo monolítico de gestão governamental, em direção a sistemas mais decentralizados e baseados no mercado." (tradução livre do autor) (WORLD BANK. The World's Bank Role in the Electric Power Sector. Washington: The World Bank, 1993, p. 14).

${ }^{41}$ Para uma leitura sobre o conjunto de medidas do "Consenso de Washington", confira-se: WILLIAMSON, J. What Washington Means by Policy Reform. In: Latin American Adjustment: How Much Has Happened? Williamson, J. (org.) Washington: Institute for International Economics, 1990, p. 7-20.

${ }^{42}$ Cf.BRASIL. Plano Diretor da Reforma do Aparelho do Estado. Câmara da Reforma do Estado, Brasília: Presidência da República, 1995, p. 57.

${ }^{43}$ Cf.PRADO, M. The Challenges and Risks of Creating Independent Regulatory Agencies: A Cautionary tale from Brazil. In: Vanderbilt Journal of Transnational Law, v. 41, março de 2008, p. 435. 
para a manutenção de capitais privados nos setores de infraestrutura. ${ }^{44}$ Assim, partir de 1996 foram estabelecidas agências reguladoras para os setores de eletricidade, telecomunicações, petróleo, transportes e outros setores da economia.

Pacheco (2006) assinala que há uma diferença fundamental na motivação para a criação das agências reguladoras no Brasil e nos Estados Unidos: a maior presença do Estado, no caso dos Estados Unidos, e a menor presença de Governo, no caso do Brasil:

"No Brasil, a criação das agências reguladoras independentes sucede uma longa tradição intervencionista do Estado na economia e nos mercados. Com um Estado vigoroso e a frequente politização de decisões que afetam a lógica de setores de infraestrutura, o debate em torno da regulação tende a valorizar a despolitização. A necessidade de autonomia para os entes reguladores visa criar credibilidade, junto aos investidores agora privados, de que regras não serão alteradas ou tarifas e preços não serão controlados segundo critérios políticos. Assim, uma diferença fundamental a assinalar nas experiências dos EUA e Brasil, refere-se à natureza das relações entre regulação e poder do Estado. A autonomia das agências, para os new dealers, reforçava o poder do Estado, enquanto no Brasil, nos anos 1990, a concessão de independência às novas agências reguladoras buscou reduzir as

${ }^{44}$ Para a Casa Civil, "[...] a presença das agências reguladoras é indispensável para o sucesso dos investimentos privados, que são centrais para suprir o déficit de investimento em infraestrutura existente no Brasil. Isto se dá porque importante parte deste investimento terá que ser arcada pelo setor privado, e investimentos em infraestrutura envolvem significativos custos irrecuperáveis ("sunk costs"), amortizados por um longo prazo de tempo. Em qualquer país, essa situação cria riscos de que tanto empresas quanto governo ajam de forma oportunista: de um lado, uma vez assegurada a concessão (monopólio) de um serviço público essencial, surge para a empresa investidora a oportunidade de pleitear benefícios não previstos inicialmente. Por outro lado, pela ótica do governo, uma vez que a empresa concessionária já realizou significativo investimento fixo, surge o incentivo de remunerá-lo abaixo do nível eficiente. Para contrapor-se a estes incentivos naturais, mas conflitantes e ineficientes, o governo necessita garantir e fortalecer o papel das agências, autônomas e independentes, como reguladores desses setores." (BRASIL. Casa Civil. Análise e Avaliação do Papel das Agências Reguladoras no Atual Arranjo Institucional Brasileiro. (Relatório do Grupo De Trabalho Interministerial). Brasília: Presidência da República. setembro de 2003.). 
incertezas, para o investidor, advindas do legado intervencionista do Estado." 45

\section{A independência formal das agências reguladoras}

Para Bresser Pereira (1998) as agências reguladoras devem ser dotadas de maior autonomia de gestão (ou autonomia administrativa) e também de maior autonomia política, em razão de executarem políticas permanentes de Estado, ou seja a regulação de preços de serviços públicos monopolistas, determinando o preço que seria o de mercado se mercado houvesse. ${ }^{46}$

Justen Filho (2002) analisa a questão da independência das agências reguladoras sob os aspectos de autonomia estrutural, autonomia econômicofinanceira e autonomia funcional.

A autonomia estrutural pode ser analisada sob os aspectos de natureza jurídica, de inserção da agência na estrutura de poder político e em sua configuração estrutural propriamente dita.

Sob o aspecto de natureza jurídica, Justen Filho (2002) leciona que, determinada a natureza jurídica de autarquia às agências reguladoras, é indispensável lei específica para sua criação, de iniciativa privativa do Poder Executivo, na forma prevista pelo ordenamento constitucional. Deve haver lei para a atribuição de competências específicas, para a criação de cargos e para a determinação de procedimentos administrativos que possam afetar direitos de terceiros, conforme previsão da Carta Magna. ${ }^{47} \mathrm{O}$ Supremo Tribunal Federal não reconheceu ainda a delegação de competência para auto-organização às agências reguladoras, quando do

${ }^{45}$ Cf.PACHECO, Regina Silvia. Regulação no Brasil: desenho das agências e formas de controle. Revista de Administração Pública, v. 40, nº 4, p. 523-543, jul./ago. 2006, p. 537.

${ }^{46}$ Cf.PEREIRA, L.C. Bresser. Reforma do Estado para a cidadania: a reforma gerencial brasileira na perspectiva internacional. São Paulo: Editora 34, 1998, p. 225-227.

${ }^{47}$ Cf.JUSTEN FILHO, Marçal. $\mathbf{O}$ direito nas agências reguladoras independentes. São Paulo: Dialética, 2002, p. 412. 
julgamento da Ação Direta de Inconstitucionalidade $n^{0} 1.668$, não tendo sido reconhecida competência autônoma para as agências. ${ }^{48}$

Quanto à questão topológica, defende o doutrinador a impossibilidade de atribuir às agências autonomia em relação aos três Poderes, por ausência de disposição da Constituição. O silêncio constitucional impõe que as agências reguladoras, face à suas atribuições, se insiram dentro do Poder Executivo. Aqui, evidencia-se, segundo o jurista, uma diferença fundamental do direito estadunidense, onde a Constituição remete à disciplina legislativa a configuração dos órgãos auxiliares de cada Poder. ${ }^{49}$

Como já assinalado, a configuração da estrutura das agências depende de lei. Observe-se que isto foi contemplado já nas leis formadoras das agências. ${ }^{50}$

Para Justen Filho (2002), a manutenção das agências reguladoras, considerando sua natureza de ente de direito público, pode-se dar através da destinação de verbas orçamentárias e da cobrança de taxa de fiscalização, devida em razão do exercício de poder de polícia. ${ }^{51} \mathrm{O}$ autor considera inadequada a cobrança de contribuição de intervenção no domínio econômico, por entender que esta tem a função de influenciar, por si mesma, o desempenho do mercado, ao invés de arrecadar recursos para órgãos regulatórios. ${ }^{52}$

A autonomia funcional das agências refere-se a sua capacidade de editar normas, fiscalizar sua aplicação e resolver litígios, em uma atividade

${ }^{48}$ Cf. BRASIL. Supremo Tribunal Federal. ADI $n^{0}$ 1.668. Disponível em: http://www.lexml.gov.br/urn/urn:lex:br:supremo.tribunal.federal;plenario:acordao;ad i:1998-08-20;1668-3714089. Acesso em 14/03/2012.

${ }^{{ }^{49} \mathrm{Cf} . J U S T E N}$ FILHO, Marçal. $\mathbf{O}$ direito nas agências reguladoras independentes. São Paulo: Dialética, 2002, p. 417.

${ }^{50} \hat{E}$ interessante destacar que no que tange ao regime jurídico aplicável ao pessoal, foram suspensos os efeitos do art. $1^{\circ}$ da Lei 9.986/2000 por força de liminar na Ação Direta de Inconstitucionalidade $\mathrm{n}^{0}$ 2.310, quando manifestou-se o Ministro Marco Aurélio no sentido de ser incompatível o exercício de poder de polícia, típico das atividades de fiscalização, com outro regime que não o regime estatutário. Com a revogação do art. $1^{\circ}$ da Lei 9.986/2000 pela Lei 10.871/2004, a referida ação perdeu o objeto.

${ }^{51}$ Cf.JUSTEN FILHO, Marçal. O direito nas agências reguladoras independentes. São Paulo: Dialética, 2002, p. 476-478.

${ }^{52}$ Op. cit., p. 479.

Revista de Direito, Estado e Telecomunicações, v. 5, n. 1, p. 135-174 (2013)

DOI: https://doi.org/10.26512/1str.v5i1.21565 
denominada pela doutrina como quase jurisdicional. No que se refere à produção de normas, Justen Filho (2002) defende que a competência normativa das agências - de forma distinta àquela atribuída às agências reguladoras norte-americanas - não as permite inovar na ordem jurídica. $\mathrm{O}$ ato legislativo, para o doutrinador, deve disciplinar extensamente a matéria, não podendo limitar-se ao estabelecimento de um padrão geral. ${ }^{53}$

Em sentido oposto, Aragão (2002), com base em uma justificativa funcional dos regulamentos autônomos ${ }^{54}$, defende que a Administração, de forma geral, poderá regulamentar uma prestação de serviço a qual a Constituição the atribui a responsabilidade, ainda que não haja uma lei ordinária disciplinando a matéria. ${ }^{55}$ Sobre o tema, Aragão defende o poder normativo de forma clara:

"Com efeito, devemos observar que o Poder Legislativo, face à complexidade, dinamismo e tecnização da sociedade, tem distinguido os aspectos políticos dos de natureza preponderantemente técnica da regulação social, retendo os primeiros, mas, consciente de suas naturais limitações, transpassando a outros órgãos ou entidades, públicas ou privadas, a normatização de caráter eminentemente técnico. (...) A necessidade de descentralização normativa, principalmente de natureza

${ }^{53}$ Op. cit., p. 525.

${ }^{54} \mathrm{~A}$ justificativa funcional dos regulamentos autônomos relaciona-se à ideia que, se à Administração é imposto o dever de prover ao interesse público, isto lhe impõe também a titularidade dos poderes necessários e correspondentes, o que pode importar na necessidade do exercício de poderes regulamentares. Em outras palavras, há uma competência-meio implícita na atribuição da competência fim. (JUSTEN FILHO, Marçal. 0 direito nas agências reguladoras independentes. São Paulo: Dialética, 2002, p. 492) Esta justificativa é denominada no direito americano como a doutrina dos poderes implícitos (implied powers), elaborada por Hamilton.

${ }^{55}$ Nas palavras de Aragão (2002), "Se, por exemplo, a Constituição estabelece que a Administração Pública deve prestar determinado serviço público (fim), não teria sentido que ela, independentemente da existência de lei ordinária, não pudesse regulamentar a sua prestação (meio). Nestas circunstâncias, só alcançarão os seus propósitos se estas (regulamentares) forem admitidas. Com isto, não estamos "forçando' o conteúdo da Constituição, mas apenas aplicando o vetusto princípio dos implied powers (...)" (ARAGÃO, Alexandre Santos de. Princípio da legalidade e poder regulamentar no Estado contemporâneo. Boletim de Direito Administrativo, v. 5, maio/2002, p. 380). 
técnica, é a razão de ser das entidades reguladoras independentes, ao que podemos acrescer o fato da competência normativa, abstrata ou concreta, integrar o próprio conceito da regulação." 56

A competência autônoma de edição de normativos técnicos pelos órgãos reguladores integra o próprio conceito e finalidade das agências reguladoras. Assim, em que pese o dissídio doutrinário sobre o tema, defende-se que a competência normativa é essencial.

Da mesma forma, o exercício da composição de litígios integra as competências estabelecidas para as agências reguladoras. Ao interessado, não é impedida a via judicial. Todavia, a especificidade dos temas levados a cada agência torna mais fácil sua compreensão pelo árbitro administrativo do que por um magistrado.

Seidman e Gilmour (1996) relatam que o crescimento do Estado regulador tornou o Judiciário um participante ativo do jogo administrativo, deixando o papel de árbitro relativamente neutro. Para os autores, a externalização dos conflitos entre as agências reguladoras e os agentes econômicos do setor regulado trará ao Judiciário um papel significativo, senão o mais importante ente os atores do processo administrativo. ${ }^{57}$

Para Dupuis e Guédon (1991), a multiplicação e a diversidade das instituições especializadas na Administração Pública trazem exigências contraditórias: de um lado, autonomia e especialização; e de outro, coerência ou unidade da atividade administrativa. ${ }^{58}$

Binenbojm (2008) defende que as agências devem submeter-se às políticas públicas traçadas pelo Poder Executivo:

“(...) a submissão dos órgãos reguladores às políticas públicas traçadas pela Administração Central é uma forma de controle pelo Poder Executivo que se encontra prevista nas próprias leis instituidoras das agências. A competência dos Ministérios para, nos termos do art. 87,

${ }^{56} \mathrm{Cf}$.ARAGÃO, Alexandre Santos de. As agências reguladoras independentes e a separação de poderes: uma contribuição da teoria dos ordenamentos setoriais. Revista Diálogo Jurídico, Salvador, nº 13 , abril-maio de 2001.

${ }^{57}$ Cf.SEIDMAN, Harold; GILMOUR, Robert. Politics, Position and Power. New York: Oxford University Press, p. 132.

${ }^{58}$ Cf.DUPUIS, Georges; GUÉDON, Marie-José. Droit Administratif. $3^{\text {a }}$ ed., Paris: Armand Colin, 1991, p. 231. 
parágrafo único, inciso I, da Constituição, exercerem 'a orientação, coordenação e supervisão dos órgãos e entidades da administração federal' tem na lei o seu fundamento e o seu limite. É desejável assim, que 0 desenho dos marcos legais da relação entre o governo e agências seja equilibrado, de modo a preservar uma base de autonomia para os reguladores sem isolá-los completamente das diretrizes gerais ditadas pelos governos democraticamente eleitos. Ademais, não seria incompatível com o regime de autonomia que a lei contivesse previsão de recursos hierárquicos impróprios das decisões das agências à Chefia do Executivo, em situações excepcionais e de grande relevância social. Esta seria uma forma legalizada de comunicação entre regulação e política pública governamental." ${ }^{.59}$

Para Kagan (2000) não é razoável atribuir ao Chefe do Executivo um poder sobre as agências reguladoras independentes com base em sua responsabilidade por toda a Administração, pois isto "subverte as premissas e a estrutura de funcionamento das agências." 60

${ }^{59} \mathrm{Cf}$.BINENBOJM, Gustavo. Temas de direito administrativo e constitucional: artigos e pareceres. Rio de Janeiro: Renovar, 2008, p. 110.

${ }^{60}$ Nas palavras de Kagan (2000): "But if Congress, as it usually does, simply has assigned discretionary authority to an agency official, without in any way commenting on the President's role in the delegation, then an interpretive question arises. One way to read a statute of this kind is to assume that the delegation runs to the agency official specified and to that official alone. But a second way to read such a statute is to assume that the delegation runs to the agency official specified, rather than to any other agency official, but still subject to the ultimate control of the President. The lawfulness of a President's use of directive power depends on the choice between these two readings. The availability of presidential directive authority thus usually will turn on the selection of an interpretive principle - really, a presumption - with which to approach a statutory delegation to an administrative official. The principle that advocates of the conventional view implicitly have adopted reads a standard delegation as excluding the President, in the absence of evidence to the contrary. The contrary principle would read a standard delegation as including the President, unless Congress indicates otherwise. Either principle would give clear guidance to courts and, equally important, provide Congress with a clear default rule against which to legislate. The choice between them appropriately rests on other considerations: in the first instance, on a judgment about legislative intentions; and to the extent these are in doubt, on a judgment about institutional competencies. When the delegation in question runs to the members of an independent agency, the choice between these two interpretive principles seems fairly obvious. In establishing such an agency, Congress has acted self-consciously, 


\section{A estabilidade dos dirigentes como núcleo central da independência das agências}

A estabilidade dos dirigentes é o núcleo central de garantia institucional da independência das agências reguladoras. ${ }^{61}$ Se o Presidente tem poderes para a exoneração ad nutum, a possibilidade de afastamento de um diretor o incentiva a agir de acordo com as preferências do Chefe do Executivo.

No Brasil, os dirigentes das agências reguladoras não podem ser exonerados durante o curso de seu mandato, excetuadas as hipóteses de renúncia, condenação judicial transitada em julgado e processo administrativo disciplinar, podendo outros motivos serem previstos nas leis específicas de cada agência. ${ }^{62}$ É prevista uma não coincidência dos mandatos dos dirigentes ${ }^{63}$, o que pode levar, na hipótese de sucessão presidencial, à atuação do Presidente eleito com dirigentes nomeados por seu antecessor.

A forma colegiada de decisão favorece a independência das agências reguladoras. Em que pese a presença de mecanismos para influenciar a decisão dos diretores, torna-se mais difícil influenciar um grupo do que um único indivíduo, em especial se os mandatos são escalonados, com início e

by means of limiting the President's appointment and removal power, to insulate agency decision-making from the President's influence. In then delegating power to that agency (rather than to a counterpart in the executive branch), Congress must be thought to intend the exercise of that power to be independent. In such a case, the agency's heads are not subordinate to the President in other respects; making the heads subordinate in this single way would subvert the very structure and premises of the agency." (KAGAN, Elena. Presidential Administration. Harvard Law Review, v. 114, 2001, p. 2326-2327).

${ }^{61}$ Cf.PRADO, M. The Challenges and Risks of Creating Independent Regulatory Agencies: A Cautionary Tale from Brazil. Vanderbilt Journal of Transnational Law, v. 41, n 2, março de 2008, p. 467.

${ }^{62}$ Confira-se a Lei 9.986/2000, art. $9^{\circ}$ : "Os Conselheiros e os Diretores somente perderão o mandato em caso de renúncia, de condenação judicial transitada em julgado ou de processo administrativo disciplinar".

${ }^{63}$ Confira-se a Lei 9.986/2000, art. 70: "A lei de criação de cada agência disporá sobre a forma de não coincidência de mandato". 
término em períodos diferenciados, e com duração superior ao mandato do Chefe do Executivo. ${ }^{64}$

\section{A questão da legitimidade}

Majone (1996) defende que a regulação por agências reguladoras apresenta uma responsabilização política insuficiente ${ }^{65}$, o que para Melo (2001), traduz-se em um déficit democrático. ${ }^{66}$

Para Silva (2002) há um déficit democrático na legitimidade das agências reguladoras, pois

"definindo-se as agências como autoridades independentes, não há garantias de que atuarão democraticamente, havendo necessidade de aperfeiçoamento das formas de participação popular em suas atividades" $"$. 0 autor defende que apenas com a "subordinação dos dirigentes máximos [das agências reguladoras] ao poder político, diretamente designado pelo povo", a independência das agências reguladoras "se compatibiliza com o ordenamento constitucional, em especial com o Princípio do Estado Democrático de Direito." ${ }^{68}$

Todavia, o mesmo autor defende que a legitimidade de qualquer parcela de poder advém da submissão "ao feixe de princípios e normas que têm como função essencial cumprir os objetivos fundamentais do estado, declarados no texto constitucional.” (SILVA, 2002, p. 152).

${ }^{64}$ Cf.PRADO, M. The Challenges and Risks of Creating Independent Regulatory Agencies: A Cautionary Tale from Brazil. Vanderbilt Journal of Transnational Law, v. 41, nº 2, março de 2008, p. 468; 483.

${ }^{65}$ Além da responsabilização política insuficiente dos reguladores, Majone (1996) aponta para a captura dos reguladores pelas firmas reguladas, a supercapitalização, a regulação anticompetitiva e a fraca coordenação entre os diferentes coordenadores como falhas da regulação através de agentes reguladores. (MAJONE, Giandomenico. Regulating Europe. Londres: Routledge, 1996).

${ }^{66}$ Cf.MELO, Marcus André. A política da ação regulatória: responsabilização, credibilidade e delegação. Revista Brasileira de Ciências Sociais, v. 16, $\mathrm{n}^{\circ} 46$, junho 2001, p. 56.

${ }^{67}$ Cf.SILVA, Francisco Quadros da. Agências reguladoras: a sua independência e o princípio do Estado Democrático. Curitiba: Juruá, 2002, p. 143.

${ }^{68}$ Idem, Ibidem. 
Cuéllar (2000) entende que a legitimação das agências não vem de sua origem, mas de sua atuação:

"[...] embora a legitimidade da atividade normativa das agências reguladoras não decorra da investidura popular, já que não são órgãos democraticamente formados, ela pode ser justificada não somente em razão da importância das atribuições exercidas pelas agências, mas também em virtude da maneira como são desenvolvidas suas tarefas ( de forma técnica, especializada e imparcial), permitindo-se, inclusive, que os particulares participem diretamente da elaboração de diplomas normativos. ${ }^{.69}$

Moreira (1997) defende que a legitimação das agências reguladoras decorre da legitimação técnica de seus membros:

"[...] a legitimidade da administração independente decorre portanto da autolegitimação pessoal dos seus membros, pela sua reputação e prestígio, pelo seu desempenho independente na condução do cargo, podendo falar-se por isso numa espécie de "legitimação técnica"”o".

Majone (1997) defende que a legitimidade das instituições depende da capacidade das mesmas em criar e manter a crença que estas são as mais apropriadas para cumprir a função a elas designada. $\mathrm{O}$ autor destaca que os critérios relevantes de legitimidade substantiva são

"a consistência nas políticas; a habilidade técnica e de solução de problemas pelos reguladores; sua habilidade em proteger interesses difusos; o profissionalismo; e o mais importante, a definição clara dos objetivos da agencia e dos limites dentro dos quais a agencia deve operar." $" 11$

Para o autor, as agências atendem ainda aos requisitos de legitimidade procedimental, pois são criadas por leis aprovadas em procedimentos

${ }^{69} \mathrm{Cf}$.CUÉLLAR, Leila. O poder normativo das agências reguladoras brasileiras. (Tese de Doutorado). Universidade Federal do Paraná, Curso de Pós-Graduação em Direito, Curitiba, 2000.

${ }^{70}$ Cf.MOREIRA, Vital. Administração autônoma e associações públicas. Coimbra: Coimbra Editora, 1997, p. 132.

${ }^{71}$ Cf.MAJONE, Giandomenico. From the Positive to the Regulatory State: Causes and Consequences of Changes in the Mode of Governance. Journal of Public Policy, v. 17, n 2, maio/agosto de 1997, p. 161. 
democráticos, que definem sua autoridade legal e seus objetivos, seus diretores são nomeados por autoridades eleitas, o processo de decisão segue normas que com frequência incluem mecanismos de participação popular, e finalmente, as decisões das agências são justificadas e abertas à revisão judicial.

O meio mais básico e simples de melhorar a transparência e a prestação de contas (accountability) é exigir que as autoridades reguladoras expusessem as razões que fundamentam suas decisões. A fundamentação das decisões permite o exercício de diversos mecanismos para controlar a discricionariedade no processo de regulação, como a revisão judicial, a participação e deliberação popular, a revisão por pares, e a análise das políticas para justificar as prioridades regulatórias, entre outros. Esta forma de organização atende ao critério madisoniano de democracia: dividir, dispersar, delegar e limitar o poder. ${ }^{72}$

Assim, não se mostra razoável a redução da legitimação das agências reguladoras à submissão ao Chefe do Poder Executivo, com base em um princípio de hierarquia.

\section{A independência real das agências reguladoras}

Majone (1997) relata diversos estudos realizados nos Estados Unidos que comprovam que as preferências de políticas públicas nos comitês parlamentares com responsabilidade pela supervisão tem um papel importante na determinação das ações pelas agências reguladoras. ${ }^{73}$

Halberstam (2010) destaca que o Estado tem diversas formas de limitar a discricionariedade das agências reguladoras: o controle judicial, a supervisão substantiva e de orçamento pelo Poder Executivo e pelo Poder Judiciário, o envio de relatórios como meio de persuasão e o estabelecimento de procedimentos de ratificação, ou homologação, pelos Ministérios responsáveis (Alemanha) ou até mesmo o encerramento das

${ }^{72}$ Op. cit., p. 160.

${ }^{73}$ Op. cit., p. 155. 
atividades da agência, com a exoneração do quadro e recriação da agência anos depois (França). ${ }^{74}$

Em sua definição de independência das agências reguladoras, Rigolon (1996) destaca a diferença entre independência legal e independência real:

"A independência da agência reguladora pode ser definida como a sua capacidade de buscar prioritariamente os objetivos de bem-estar do consumidor e de eficiência produtiva e alocativa da indústria, em detrimento de outros objetivos conflitantes, tais como a maximização do lucro do monopolista, a concentração das firmas em segmentos mais lucrativos do mercado, a maximização de receitas fiscais etc. A independência legal mostra que grau de independência os legisladores desejaram conferir à agência e é um componente importante da independência real. A independência real depende não só do grau de independência conferido pela lei, mas também de outros fatores menos visíveis, tais como o relacionamento entre a agência, o governo e a indústria regulada, a qualidade de seu corpo técnico, a disponibilidade de recursos para o seu funcionamento e até mesmo as personalidades de indivíduos-chave no governo e na indústria." 75

Para Cavalcanti (2000), o exercício de um poder regulador por entes autônomos encontra maiores dificuldades no Brasil onde o poder regulamentar está adstrito ao papel de mero instrumento de aplicação da lei. ${ }^{76} \mathrm{O}$ impacto na opinião pública da atuação das agências, em especial no que tange à revisão tarifária, pode provocar tensão no relacionamento entre as agências reguladoras e o Poder Executivo. ${ }^{77}$

${ }^{74}$ Cf.HALBERSTAM, Daniel. The Promise of Comparative Administrative Law: a Constitutional Perspective on Independent Agencies. In: ROSE-ACKERMAN, S. e LINDSETH, P. Comparative Administrative Law. Cheltenham: Edward Elgar, 2010, p. 189.

${ }^{75}$ Cf.RIGOLON, Francisco José Zagari. Regulação da infraestrutura: a experiência recente no Brasil. Disponível em: http://www.bndes.gov.br/SiteBNDES/export/sites/default/bndes_pt/Galerias/Arquiv os/conhecimento/revista/rev705.pdf. Acesso em: 13/03/2011.

${ }^{76}$ Cf.CAVALCANTI, Francisco de Queiroz Bezerra. A independência da função reguladora $e$ os entes reguladores independentes. In: Revista de Direito Administrativo, $\mathrm{n}^{\circ} 219$, jan/mar 2000, p. 255.

${ }^{77}$ Binenbojm (2008) relata a discordância pelo Chefe do Poder Executivo de uma revisão tarifária, e a retaliação subsequente: "Em fevereiro de 2003, o Presidente 
Prado (2008) destacou, com base em evidências empíricas, que há grande influência do Presidente sobre as agências reguladoras no Brasil. ${ }^{78} 79$ Para a autora, a percepção da população de que o Presidente é responsável pelas agências - mesmo após as privatizações - incentiva ingerências indiretas do Chefe do Poder Executivo no sentido de reduzir tarifas para auferir benefícios eleitorais. Ainda que não haja interferências oportunistas, o Chefe do Executivo é motivado a interferir para que as decisões das

Lula saiu de uma reunião ministerial e declarou aos mais importantes jornais e redes de TV que 'as agências mandam no país'. Ele reclamou também que era avisado dos aumentos de tarifas de serviços públicos pelos jornais e que as decisões que mais afetavam a população não passavam pelo governo. Logo em seguida, em março de 2003, Lula designou uma comissão para discutir uma proposta legislativa de reforma da estrutura das agências. De outra parte, o governo iniciou um acalorado debate público com as agências de telecomunicações (ANATEL) e energia elétrica (ANEEL) tendo por objetivo a revisão das tarifas telefônicas e de energia, cujo exame estava em curso. Por evidente, não interessava a um governo popular que, logo em seu começo, medidas impopulares - como o aumento de tarifas - fossem determinadas pelas agências. Na percepção da opinião pública, tais medidas seriam certamente atribuídas ao governo como um todo. (BINENBOJM, Gustavo. Temas de direito administrativo e constitucional: artigos e pareceres. Rio de Janeiro: Renovar, 2008, p. 22).

${ }^{78} \mathrm{Cf} . \mathrm{PRADO}, \mathrm{M}$. The Challenges and Risks of Creating Independent Regulatory Agencies: A Cautionary Tale from Brazil. Vanderbilt Journal of Transnational Law, v. 41, ${ }^{0} 2$, março de 2008.

${ }^{79} \mathrm{Em}$ pesquisa realizada pela American Chamber of Commerce - Brasil junto a agentes das áreas jurídica, de regulação e de relações com o governo do setor regulado em 2010, foi levantada a percepção de 63,89\% dos entrevistados de que a Agência Nacional de Telecomunicações (ANATEL) sempre sofre interferências políticas. Para $25,81 \%$ dos entrevistados, a ANATEL geralmente sofre interferências políticas. (AMCHAM. Relatório sobre a Agência Nacional de Telecomunicações 2010 , p. 47. Disponível em: http://www.amcham.com.br/repositorio-dearquivos/relatorio-anatel-2010. Acesso em 11/03/2013). Em pesquisa semelhante realizada em 2009 junto ao setor de energia elétrica, quanto ao nível de interferência do Governo, por meio de seus Ministérios, nas decisões e ações de regulação e fiscalização da Agência Nacional de Energia Elétrica (ANEEL), 54,55\% dos entrevistados a consideram alto, e 9,09\% a consideram máxima. (AMERICAN CHAMBER OF COMMERCE - BRASIL. Relatório sobre a Agência Nacional de Energia Elétrica - 2009, p. 37. Disponível em: http://www.amcham.com.br/repositorio-de-arquivos/relatorio-aneel-2009. Acesso em 11/03/2013). 
agências reguladoras não venham a interferir com políticas macroeconômicas ou sociais da Administração. ${ }^{80}$

A jurista entende que a aprovação da Lei Geral de Telecomunicações, com amplo detalhamento do quadro regulatório e maiores garantias de independência para o ente regulador, permitiu à Agência Nacional de Telecomunicações (ANATEL) uma maior independência em relação à Agência Nacional de Energia Elétrica, cuja lei de criação sofreu numerosas emendas parlamentares que prejudicaram a integração de suas garantias institucionais de independência. ${ }^{81}$

Em que pese a proibição legal de exoneração dos diretores das agências reguladoras, com as exceções determinadas pela lei, a duração do mandato do presidente de uma agência reguladora - escolhido pelo Presidente entre os membros da diretoria - é determinação discricionária do Chefe do Executivo. Desta forma, através do estabelecimento de períodos curtos, o Presidente detém forte poder de interferência sobre as agências reguladoras. ${ }^{82}$ Soma-se a isso o fato de que a nomeação dos diretores das agências é uma prerrogativa do Presidente da República. ${ }^{83}$ A prática do

${ }^{80} \mathrm{Cf} . \mathrm{PRADO}, \mathrm{M}$. The Challenges and Risks of Creating Independent Regulatory Agencies: A Cautionary Tale from Brazil. Vanderbilt Journal of Transnational Law, v. 41, n ${ }^{0}$ 2, março de 2008, p. 446-447.

${ }^{81}$ Op. cit., p. $465-466$.

${ }^{82}$ Cf.Lei 9.986/2000, artigo $5^{\circ}$, parágrafo único: "O Presidente ou o Diretor-Geral ou o Diretor-Presidente será nomeado pelo Presidente da República dentre os integrantes do Conselho Diretor ou da Diretoria, respectivamente, e investido na função pelo prazo fixado no ato de nomeação." Excetua-se deste procedimento a ANEEL, por prever em sua lei um cargo específico de diretor-geral com mandato de quatro anos. (Vide Lei 9.427/1996, art. $5^{\circ}$ ).

${ }^{83} \mathrm{~A}$ nomeação pelo Presidente da República baseia-se na previsão constitucional do Art. 84, XIV ("Compete privativamente ao Presidente da República (...) nomear, após aprovação pelo Senado Federal, os Ministros do Supremo Tribunal Federal e dos Tribunais Superiores, os Governadores de Territórios, o Procurador-Geral da República, o presidente e os diretores do banco central e outros servidores, quando determinado em lei") e das seguintes leis das agências reguladoras: Lei 9.472/1997, art. 23 (ANATEL); Lei 9.427/1996, art. $5^{\circ}$ (ANEEL), Lei 9.478/1997, art. 11 (ANP); Lei 9.782/1999, art. 10 (ANVISA); Lei 9.961/2000, art. 6 (ANS); Lei 9.984/2001, art. $9^{\circ}$ (ANA); Lei 10.233/2001, art. 53 (ANTAQ e ANTT); Medida Provisória 2.228-1/2001 (ANCINE).

Revista de Direito, Estado e Telecomunicações, v. 5, n. 1, p. 135-174 (2013)

DOI: https://doi.org/10.26512/1str.v5i1.21565 
Senado federal é de aprovação das indicações do Presidente, e o veto foi exercido apenas excepcionalmente. ${ }^{84}$

Prado (2008) destaca ainda que o poder do Chefe do Executivo sobre o orçamento das agências reguladoras através da Lei Geral do Orçamento e do processo orçamentário atribuem, na prática, um poder de controle do Presidente sobre as mesmas. As multas e demais arrecadações da agência, embora destinados à agência, são integrados desde 1998 no Orçamento Geral da União, e sua utilização depende de aprovação do Chefe do Poder Executivo. Xavier (2011) realizou estudo que comprova que o contingenciamento, as imposições de limitações de empenho e os limites orçamentários inferiores à arrecadação de receita própria têm enfraquecido a autonomia financeira da Agência Nacional de Energia Elétrica. ${ }^{85}$ A mesma situação ocorre nas demais agências reguladoras: em 2012, diagnóstico do Tribunal de Contas da União apontou que todas as agências reguladoras ligadas à área de infraestrutura sofrem com a falta de autonomia financeira, política, conselhos incompletos e falta de transparência. ${ }^{86}$

Observa-se que a efetiva independência das agências reguladoras está ligada ao ambiente legal, político e institucional. A simples reprodução da organização de garantias da legislação estadunidense não reflete as particularidades do quadro legal/normativo, social e político brasileiro.

${ }^{84}$ Cf.PRADO, M. The Challenges and Risks of Creating Independent Regulatory Agencies: A Cautionary Tale from Brazil. Vanderbilt Journal of Transnational Law, v. 41, n ${ }^{0}$ 2, março de 2008, p. 478-479.

${ }^{85}$ Cf.XAVIER, E. Estudo sobre a autonomia financeira e orçamentária da Agência Nacional de Energia Elétrica, analisada a partir do contingenciamento e da vinculação de despesas no Orçamento Público Federal no período compreendido entre 2000 e 2009. Caderno de Finanças Públicas, Brasília, nº 11, dez. 2011, p. 131-132.

${ }^{86}$ Conforme notícia publicada pelo jornal Valor Econômico: VALOR ECONÔMICO. "Para o TCU, Agências sofrem com falta de autonomia". Disponível em: $\quad$ http://www.valor.com.br/brasil/2693230/para-o-tcu-agencias-reguladorassofrem-com-falta-de-autonomia\#tixzz2NT2b27U3. Acesso em 13/03/2013. Vide ainda a nota 79, supra, quanto a percepção dos setores regulados sobre a interferência do Governo na ANATEL e ANEEL. 


\section{A questão do controle}

\subsection{O Controle Externo}

O Estado Democrático de Direito pressupõe a preocupação com o controle democrático do poder. As agências reguladoras são controladas pelo Tribunal de Contas da União e pela Controladoria Geral da União quanto à correta gestão dos recursos públicos, na forma dos artigos 70 e 71 da Magna Carta. A fiscalização, no entendimento de Justen Filho (2002) e Barroso (2002, p. 285-311), não poderá incidir no campo material da atividade desempenhada pelas agências, sob pena de ferir sua autonomia.

Majone (1997) destaca que o estabelecimento de um sistema de governança eficaz pode substituir o controle externo formal:

"A questão normativa chave do Estado Regulador é como a independência da agência e a governança democrática podem ser complementares e reforçar-se mutuamente ao invés de tornarem-se valores antitéticos. (...) A independência e a governança podem ser conciliadas, estabelecendo-se, ao invés de uma supervisão exercida de qualquer posição fixa do sistema político, uma combinação de mecanismos de controle: objetivos limitados e claros fixados em lei que forneçam padrões de desempenho; requisitos de fundamentação e transparência para facilitar a revisão judicial e a participação pública; previsão de um devido processo legal para assegurar a justiça para os inevitáveis vencedores e perdedores das decisões regulatórias; profissionalismo para resistir à interferência externa e reduzir o risco de utilização de um uso arbitrário do poder discricionário da agência. Com o funcionamento adequado de tal sistema de controles múltiplos, ninguém controla a agência, mas a agência está "sob controle". 87

Aguillar (1999) destaca ainda a importância do controle entre os poderes para o funcionamento adequado das agências reguladoras:

"O ponto que nos parece importante é 0 da necessidade de temperar excessos do Poder Executivo na modelagem do órgão regulador, bem como na condução de suas atividades. Essa moderação do poder do

${ }^{87}$ Cf.MAJONE, Giandomenico. From the Positive to the Regulatory State: Causes and Consequences of Changes in the Mode of Governance. Journal of Public Policy, v. 17, n 2, maio/agosto de 1997, p. 155. 
executivo somente pode ser feita mediante atribuição de poderes a outras instituições na escolha dos membros ao órgão regulador, ou mediante 0 exercício de controle externo sobre os atos do órgão regulador. Qualquer outra medida que não leve em consideração essas ponderações fatalmente não terá por efeito atenuar os poderes do Executivo na deliberação, controle e execução de políticas estatais". ${ }^{88}$

\subsection{O Controle Social}

O Estado Democrático de Direito pressupõe a existência de mecanismos de controle da sociedade sobre os atos do Governo. Mill (1983) já assinalava que a comunidade não deveria entregar toda a direção do Estado para os governantes. Para o filósofo, toda a comunidade deveria atuar como controladora suprema da vida social, reservando aos cidadãos o direito de, pelo menos acidentalmente, participar da forma real do governo. Para Mill (1983), "os direitos e interesses de todos ou de cada um" só são garantidos e devidamente considerados se tiverem a possibilidade permanente de expressá-los e defendê-los. Destaca, ainda, que "em um governo despótico, os cidadãos são totalmente passivos, não participando das decisões que dizem respeito à comunidade." $" 89$

Aguillar (1999) considera que o controle social depende de mecanismos institucionais que permitam sua existência, bem como mecanismos de poder que lhe deem efetividade:

"Há basicamente duas frentes de avaliação da capacidade de controle social de serviços públicos. De um lado, o controle que efetivamente caiba a setores da sociedade diretamente sobre os serviços públicos, sejam eles desempenhados por empresas privadas ou pelo próprio estado. De outro lado, o poder de que desfrute a sociedade para interferir nas decisões estatais a respeito dos órgãos reguladores, na sua composição e modelagem." ${ }^{00}$

${ }^{88}$ Cf.AGulLlaR, Fernando Herren. Controle Social de Serviços Públicos. São Paulo: Max Limonad, 1999, p. 238.

${ }^{89}$ Cf. MILL, John Stuart. O Governo Representativo. São Paulo: Ibrasa, 1983, p. $35-43$.

${ }^{90}$ Cf.AGUILlaR, Fernando Herren. Controle Social de Serviços Públicos. São Paulo: Max Limonad, 1999, p. 248. 
O autor considera positivo, nas agências reguladoras, a criação da Ouvidoria, a prática de audiências públicas e destaca a instituição do Conselho Consultivo da ANATEL, órgão opinativo com doze membros, sendo dois indicados pelo Senado Federal, dois pela Câmara dos Deputados, dois por entidades de classe das prestadoras de serviços de telecomunicações, dois pelas entidades representativas dos usuários e dois pelas entidades representativas da sociedade..$^{11}$

Para o jurista, faltam ainda instrumentos que deem aos usuários maior poder de fato nos processos decisório e de fiscalização:

"Na sociedade democrática, nem o controle estatal pleno, nem 0 controle social absoluto são desejáveis. É preciso que haja uma permeabilidade entre a sociedade e o Estado. Na democracia, o Estado ganhará legitimação na medida dessa capacidade de permitir a influência da população no exercício do poder constituído. À simples legitimação do poder pela origem, contrapõe-se, portanto, a legitimação pelo exercício do poder. (...) A participação popular teria o mérito de aproximar a prestação dos serviços públicos [dessas] exigências. Ela pode tornar flexível a aplicação das normas que regem a concessão, posto que são os usuários desses serviços aqueles que mais conhecimento detêm acerca das deficiências de sua prática. E pode substituir tanto a falta de motivação do Estado quanto o conflito de interesses dos concessionários, pelo zelo dos que constituem os maiores beneficiários do bom andamento dos serviços. É importante ressaltar que o controle social exercido através da participação popular albergada pelo aparelho jurídico estatal e não meramente a manifestação espontânea dos interesses da população; é preciso organizar, institucionalizar espaços de veiculação de interesses. E isso somente é possível fazer amparando-os através do Direito." ${ }^{.2}$

${ }^{91}$ Confira-se o artigo $2^{\circ}$ do Regimento Interno do Conselho Consultivo da ANATEL, de 2002.

${ }^{92}$ Cf.AGuILlaR, Fernando Herren. Controle Social de Serviços Públicos. São Paulo: Max Limonad, 1999, p. 293.

Revista de Direito, Estado e Telecomunicações, v. 5, n. 1, p. 135-174 (2013)

DOI: https://doi.org/10.26512/1str.v5i1.21565 


\section{Tendências: haverá espaço político para a independência das agências reguladoras?}

Em 2004, o Poder Executivo encaminhou ao Congresso o Projeto de Lei $\mathrm{n}^{\mathrm{o}} 3.337 / 2004$, que conferia estabilidade aos dirigentes durante a vigência de seus mandatos de quatro anos, deixando a cada novo presidente da República a faculdade de nomear novos dirigentes, no período compreendido entre o $7^{\circ}$ e o $18^{\circ}$ mês de mandato; introduzia o contrato de gestão para todas as agências, a ser supervisionado pelo ministro setorial, e condicionava o repasse de recursos orçamentários ao cumprimento de metas administrativas e de desempenho preestabelecidos; criava a figura do ouvidor independente em cada agência, e disciplinava o acompanhamento das consultas públicas realizadas pela agência por até três representantes de associações de usuários, com despesas custeadas pela agência. O projeto também disciplinava o processo decisório nas agências, estendendo a todas as agências os mecanismos de decisão colegiada e de consulta pública, e propunha a uniformização das regras para todas elas. ${ }^{93}$

Arquivado em 2006 e desarquivado ao início das duas sessões legislativas seguintes, o Projeto de Lei foi apensado a dois outros projetos de lei sobre o tema e aguardava a criação de uma comissão especial para sua análise. Em 14 de março de 2013, o Projeto de Lei 3.337/2004 foi retirado do Congresso pela Presidência. ${ }^{94}$

Em 13 de março de 2013, foi publicada, no Diário Oficial da União, a Resolução no 4/2013, do Senado federal, que determinou o comparecimento dos presidentes das agências reguladoras para prestação de contas anual em reunião conjunta da comissão temática pertinente e das Comissões de Assuntos Econômicos e de Constituição, Justiça e Cidadania. ${ }^{95}$ Nesse

${ }^{93}$ Vide Projeto de Lei 3.337/2004. Disponível em: http://www.lexml.gov.br/urn/urn:lex:br:camara.deputados:projeto.lei;pl:2004-0413;3337. Acesso em 14/03/2013.

${ }^{94}$ Vide Folha de São Paulo. "Governo quer fortalecer agências reguladoras para proteger consumidor, diz Dilma". Disponível em: http://www1.folha.uol.com.br/mercado/1246927-governo-quer-fortalecer-agenciasreguladoras-para-proteger-consumidor-diz-dilma.shtml. Acesso em 15/03/2013. ${ }^{95}$ Vide art. $1^{\circ}$, da Resolução ${ }^{\circ}$ 4: "O Regimento Interno do Senado Federal passa a vigorar acrescido dos seguintes artigos: (...) Art. 96-A. Os dirigentes máximos das 
mesmo dia, foi noticiado pelo jornal "A Folha da São Paulo" que o Poder Executivo pretendia retirar o poder de outorga de concessões de serviços das agências, transferindo-o para os Ministérios, e vincular o repasse de verbas do orçamento ao alcance de metas estabelecidas pelos Ministérios. Segundo a notícia veiculada, a possibilidade de que o Governo fizesse as alterações através de Medida Provisória não era descartada pelas lideranças do Congresso. ${ }^{96}$

Pode-se concluir que há uma tendência de crescimento da influência do Poder Executivo e de redução do poder e da independência real das agências reguladoras em seus aspectos de autonomia estrutural, de autonomia econômico-financeira e autonomia funcional.

\section{Conclusão}

Em 1748, Montesquieu escreveu, em sua obra "O Espírito das Leis", que:

"[a] lei, em geral, é a razão humana, enquanto governa todos os povos da terra; e as leis políticas e civis de cada nação devem ser apenas casos particulares onde se aplica esta razão humana. Devem ser tão próprias ao povo para o qual foram feitas que seria um acaso muito grande se as leis de uma nação pudessem servir para outra." ${ }^{\text {97 }}$

agências reguladoras comparecerão ao Senado Federal, em periodicidade anual, para prestar contas sobre o exercício de suas atribuições e o desempenho da agência, bem como para apresentar avaliação das políticas públicas no âmbito de suas competências. Parágrafo único. O comparecimento de que trata o caput ocorrerá em reunião conjunta da comissão temática pertinente e das Comissões de Assuntos Econômicos e de Constituição, Justiça e Cidadania.” (BRASIL. Senado Federal.. Resolução n ${ }^{\circ}$ 4/2013. Brasília, 2013). Disponível em: http://www.lexml.gov.br/urn/urn:lex:br:senado.federal:resolucao:2013-03-12;4. Acesso em 15/03/2013.

${ }^{96}$ Vide Folha de São Paulo. "Governo vai premiar agências que aumentarem o rigor na fiscalização". Disponível em: http://www1.folha.uol.com.br/mercado/1245307governo-vai-premiar-agencias-que-aumentarem-o-rigor-na-fiscalizacao shtml. Acesso em 14/03/2013.

${ }^{97}$ Cf.MONTESQUIEU (Charles de Secondat, Baron de). O Espírito das Leis. São Paulo: Martins Fontes, 2000, p. 16. 
A convergência das normas legais, como resultado da globalização, não leva necessariamente à eficácia das leis. As leis mais eficazes são parte de um processo de inovação com a participação dos agentes, considerando a cultura normativa pré-existente..$^{98} \mathrm{O}$ simples transplante de estruturas legais - como é o caso das leis de criação das agências reguladoras - não assegura a independência das agências regulares em um ambiente de prevalência do Poder Executivo e reduzida participação da sociedade.

O estabelecimento de garantias eficazes para a independência das agências reguladoras é necessariamente uma solução de compromisso: se a garantia de independência é fraca, com forte interferência do governo nos assuntos regulatórios, a agenda do Poder Executivo é protegida, mas o funcionamento do setor regulado é prejudicado; se a garantia de independência é forte, haverá dificuldades na implementação da agenda do Governo, mas os setores regulados funcionarão com eficiência. ${ }^{99}$

A redução da independência das agências reguladoras e o aumento do controle do Poder Executivo tornam oportuno destacar o alerta de Aranha (2009, p. 53):

"Ao controlar o órgão regulador, a Administração Direta do Estado faz prevalecer 0 interesse político sobre a eficiência e qualidade da prestação do serviço, sobre o próprio interesse público de modicidade das tarifas e sobre 0 interesse público de equilíbrio da relação. (...) A questão da autonomia da gestão da agência reguladora apresenta-se como a pedra de toque do modelo idealizado no Brasil."

\section{Bibliografia}

AGÊNCIA NACIONAL DE TELECOMUNICAÇÕES. Regimento Interno do Conselho Consultivo. Brasília: ANATEL, 2002.

${ }^{98}$ Para um estudo detalhado sobre os transplantes de leis - objetivo que extrapola o escopo deste artigo - a vide: BERKOWITZ, Daniel; PISTOR, Katharina e RICHARD, Jean-François. The Transplant Effect. The American Journal of Comparative Law. v. 51, 2003, p. 163-204.

${ }^{99}$ Cf.PRADO, M. The Challenges and Risks of Creating Independent Regulatory Agencies: A Cautionary Tale from Brazil. Vanderbilt Journal of Transnational Law, v. 41, n ${ }^{0}$ 2, março de 2008, p. 501-502. 
AGUILlAR, F. Controle social de serviços públicos. São Paulo: Max Limonad, 1999.

AMATO, G. Autorità Semi-Indipendenti ed Autorità di Garanzia. Rivista Trimestrale di Diritto Publico, p. 645-664, 1997.

AMERICAN CHAMBER OF COMMERCE BRASIL. Relatório sobre a Agência Nacional de Telecomunicações - 2010. Disponível em: http://www.amcham.com.br/repositorio-de-arquivos/relatorio-anatel-2010. Acesso em: 11 de março de 2013.

Relatório sobre a Agência Nacional de Energia Elétrica-2009. Disponível em: http://www.amcham.com.br/repositoriode-arquivos/relatorio-aneel-2009. Acesso em: 11 de março de 2013.

ARAGÃO, A. Agências reguladoras e a evolução do direito administrativo econômico. Rio de Janeiro: Forense, 2004.

Princípio da legalidade e poder regulamentar no Estado contemporâneo. Boletim de Direito Administrativo, v. 5, p. 370-380, maio de 2002.

As agências reguladoras independentes e a separação de poderes: uma contribuição da teoria dos ordenamentos setoriais. Revista Diálogo Jurídico, v. 13, abril-maio de 2001.

ARANHA, M. Estado e regulação: metalinguagem regulatória. Mimeo. Mestrado e Doutorado em Direito, Estado e Constituição, 2012.

Direito, Estado e Telecomunicações: dos primórdios ao novo modelo regulatório. Revista de Direito, Estado e Telecomunicações, Brasília, 2009, p. 1-76.

Direito Regulatório. Apostila do Curso de Especialização em Direito Público, 2009.

Poder normativo do Executivo e teoria da regulação.

Notícia do Direito Brasileiro, Brasília, v. 9, 2002, p. 135-154.

BARROSO, L. R. Agências Reguladoras. Constituição, Transformações do Estado e Legitimidade Democrática. Revista de Direito Administrativo, Jul./Set. 2002, p. 285-311.

BERKOWITZ, D.; PISTOR, K. e. RICHARD, J.-F. The Transplant Effect. The American Journal of Comparative Law, v. 51, p. 163-204, 2003.

BINENBOJM, G. Temas de direito administrativo e constitucional: artigos e pareceres. Rio de Janeiro: Renovar, 2008.

BRASIL. Senado Federal. Resolução no 4/2013, 2013. Disponível em: http://www.lexml.gov.br/urn/urn:lex:br:senado.federal:resolucao:2013-0312;4. Acesso em: 15 de março de 2013.

- Casa Civil. Análise e Avaliação do Papel das Agências

Reguladoras no Atual Arranjo Institucional Brasileiro. (Relatório do 
Grupo de Trabalho Interministerial). Brasília: Presidência da República, 2003.

- Supremo Tribunal Federal. ADI $\mathbf{n}^{0}$ 1668. Disponível em: http://www.lexml.gov.br/urn/urn:lex:br:supremo.tribunal.federal;plenario: acordao;adi:1998-08-20;1668-3714089. Acesso em 14 de março de 2012.

. Plano Diretor da Reforma do Aparelho do Estado. Câmara da Reforma do Estado. Brasília: Presidência da República, 1995.

BRESSER-PEREIRA, L. C. Reforma do Estado para a cidadania: a reforma gerencial brasileira na perspectiva internacional. São Paulo: Editora 34, 1998.

CAVALCANTI, F. A independência da função reguladora e os entes reguladores independentes. Revista de Direito Administrativo, $\mathrm{n}^{\circ} 219$, jan./mar. 2000.

CUÉllaR, L. O Poder Normativo das Agências Reguladoras Brasileiras (Tese de Doutorado). Curitiba: Universidade Federal do Paraná, 2000.

D'ARCY, F. e DREYFUS, F. Les Institutions Politiques et Administratives de la France. Paris: Economia, 1997.

DI PIETRO, M. S. Direito administrativo. 11ª ed., São Paulo: Atlas, 1999. Parcerias na Administração Pública. 3a. ed. São Paulo:

Atlas, 1999.

DUPUIS, G. e. GUÉDON, M.-J. Droit Administratif. Paris: Armand Colin, 1991.

FEINTUCK, Mike. Regulatory Rationales Beyond the Economic: In Search of the Public Interest. In: BALDWIN, Robert; CAVE, Martin; LODGE, Martin (org.). The Oxford Handbook of Regulation. Oxford: Oxford University Press, 2010.

HALBERSTAM, D. The Promise of Comparative Administrative Law: a Constitutional Perspective on Independent Agencies. In: ROSEACKERMAN, S. e LINDSETH, P. Comparative Administrative Law. Cheltenham: Edward Elgar, 2010. Cap. 12, p. 185-204.

HORWITZ, R. B. The Irony of Regulatory Reform: the deregulation of american telecommunications. Oxford: Oxford University Press, 1989.

JUSTEN FILHO, M. O Direito das Agências Reguladoras Independentes. São Paulo: Dialética, 2002.

KAGAN, E. Presidential Administration. Harvard Law Review, Cambridge, v. 114, p. 2245-2385, 2001.

MAJONE, G. From the Positive to the Regulatory State: Causes and Consequences of Changes in the Mode of Governance. Journal of Public Policy, Cambridge, v. 17, n. 2, p. 139-167, maio/agosto 1997. 
. Regulating Europe. Londres: Routledge, 1996.

MELLO, C. A. Curso de direito administrativo. $14^{\text {a }}$ ed., São Paulo: Malheiros, 2002.

MELO, M. A. A Política da Ação Regulatória: Responsabilização, Credibilidade e Delegação. Revista Brasileira de Ciências Sociais, v. 16, n. 46, p. 55-68, junho 2001.

MILL, J. S. O governo representativo. São Paulo: Ibrasa, 1983.

MONTESQUIEU (Charles de Secondat, Baron de). O Espírito das Leis. São Paulo: Martins Fontes, 2000.

MOREIRA, E. Agências Administrativas, Poder Regulamentar e o Sistema Financeiro Nacional. Revista de Direito Administrativo, $\mathrm{n}^{\circ} 218$, out./dez. 1999.

MOREIRA, V. Administração autonoma e associações públicas. Coimbra: Coimbra Editira, 1997.

Autorregulamentação profissional e Administração Pública. Coimbra: Almedina, 1997.

MORGAN, B. e. YOUNG, K. An Introduction to Law and Regulation. Cambridge: Cambridge University Press, 2007.

OGUS, A. Regulation: Legal Form and Economic Theory. Portland: Hart, 2004.

PACHECO, R. S. Regulação no Brasil: desenho das agências e formas de controle. Revista de Administração Pública, v. 40, n. 4, p. 523-543, jul./ago. 2006.

PRADO, M. The Challenges and Risks of Creating Independent Regulatory Agencies: A Cautionary Tale from Brazil. Vanderbilt Journal of Transnational Law, Nashville, v. 41, n. 2, p. 435-503, March 2008.

PROSSER, T. Law and the Regulators. Oxford: Claredon Press, 1997.

RIGOLON, F. J. Regulação da Infra-Estrutura: a experiência recente no Brasil., $1996 . \quad$ Disponível em: http://www.bndes.gov.br/SiteBNDES/export/sites/default/bndes_pt/Galeri as/Arquivos/conhecimento/revista/rev705.pdf. Acesso em: 13 de março de 2013.

SALOMÃO FILHO, C. Regulação da Atividade Econômica: princípios e fundamentos jurídicos. São Paulo: Malheiros, 2008.

SEIDMAN, H. e GILMOUR, R. Politics, Position and Power. New York: Oxford University Press, 1996.

SELZNICK, P. Focusing Organizational Research on Regulation. In: NOLL, R. Regulatory Policy and the Social Sciences. Berkeley: University of California Press, 1985, p. 363-367. 
SHAPIRO, M. A Comparison of US and European Independent Agencies. In: ROSE-ACKERMAN, S. e. LINDSETH, P. Comparative Administrative Law. Cheltemham: Edward Elgar, 2010, p. 293-306.

SILVA, F. Agências Reguladoras: a sua independência e o princípio do Estado Democrático. Curitiba: Juruá, 2002.

SUNSTEIN, C. After the Rights Revolution: Reconceiving the Regulatory State. Cambridge: Harvard University Press, 1990.

WILLIAMSON, J. What Washington Means by Policy Reform. In: WILliAMSON, J. (org). Latin American Adjustment: How Much Has Happened? Washington: Institute for International Economics, 1990. p. 7-20.

WORLD BANK. The World's Bank Role in the Electric Power Sector. Washington: The World Bank, 1993.

XAVIER, E. Estudo sobre a Autonomia Financeira e Orçamentária da Agência Nacional de Energia Elétrica, Analisada a partir do Contingenciamento e da Vinculação de Despesas no Orçamento Público Federal no Período Compreendido entre 2000 e 2009. Caderno de Finanças Públicas, dezembro de 2011, p. 113-135. 
Revista de Direito, Estado e Telecomunicações, v. 5, n. 1, p. 135-174 (2013)

DOI: https://doi.org/10.26512/lstr.v5i1.21565 